\title{
EFEKTIVITAS PROGRAM PENINGKATAN KETERAMPILAN DUKUNGAN KEMANDIRIAN PADA PENGASUH TODDLER DI TPA X
}

\author{
Ulfa Rahmanissa dan Wahyu Indianti \\ Fakultas Psikologi, Universitas Indonesia \\ Jalan Lingkar Kampus Raya Mawar 53 8, Pondok Cina, Beji, Jawa Barat 16424 \\ Email: rahmanissa@gmail.com
}

\begin{abstract}
ABSTRAK. Anak usia toddler berada pada masa peralihan dari bayi yang bergantung penuh terhadap pengasuh menjadi mulai dapat mengerjakan pekerjaan sendiri. Pada usia ini seorang anak mulai menunjukkan perkembangan kemandirian, maka seorang anak butuh pendampingan dari orang dewasa terdekatnya untuk memberikan dukungan kemandirian. Dampak positif dari memberikan dukungan kemandirian pada anak usia toddler baru akan terlihat pada rentang usia anak yang lebih tinggi. Penelitian ini bertujuan untuk melihat efektivitas pelatihan dukungan kemandirian dalam meningkatkan keterampilan pengasuh dalam mendukung kemandirian anak usia toddler di TPA X. Pelatihan ini menggunakan dasar experiential learning, pelatihan diberikan kepada 29 pengasuh yang bekerja di 3 cabang TPA X. Pemilihan subjek menggunakan teknik accidental sampling. Pelatihan ini dilakukan sebanyak 5 sesi dalam waktu 2 hari. Penelitian ini merupakan penelitian dengan one group pre-test post-test design, yakni hanya memiliki satu kelompok perlakukan tanpa kelompok kontrol. Instrumen penelitian yang digunakan pada pretest dan post-test mengukur keterampilan dukungan kemandirian yang mengadopsi dari praktik-praktik dukungan kemandirian Côté-Lecaldare, Joussemet dan Dufour yang kemudian dirancang oleh peneliti. Hasil pre-test dan post-test 1 diuji dengan non prametric Wilcoxon Signed Rank dan menunjukkan adanya peningkatan signifikan antara hasil pre-test dengan post-test 1 maupun post-test 2 . Dengan demikian dapat disimpulkan bahwa pelatihan dukungan kemandirian efektif dalam meningkatkan keterampilan dukungan kemandirian pengasuh terhadap anak usia toddler, sehingga diharapkan pengasuh TPA X dapat menjadi agen penting yang memberikan dampak positif terhadap kemandirian anak di rentang usia yang lebih tinggi.
\end{abstract}

Kata kunci: kemandirian; dukungan kemandirian; pengasuh; tempat penitipan anak; toddler.

\section{EFFECTIVENESS OF AUTONOMY SUPPORT SKILLS IMPROVEMENT PROGRAM FOR TODDLER'S CAREGIVER IN X DAYCARE}

ABSTRACT. Toddler age children are in transition from baby with full care of caregivers to start being able to do their own work. At this age children start to show the development of autonomy, so children need assistance from caregiver to provide autonomy support. The positive impact of giving autonomy support to toddler will be seen in the higher age range of them. This study aims to look the effectiveness of Autonomy Support Training to improve caregiver skills in supporting the autonomy of toddler at TPA X. The training used experiential learning basis, training is given to 29 caregivers working in 3 branches of TPA X. Subject were selected using accidental sampling technique. This training was conducted in 5 sessions in 2 days. This study is a study with one group pre-test post-test design, which only has one treatment group without a control group. The research instrument used in the pretest and post-test measures the autonomy support skills adopted from autonomy support practices Côté-Lecaldare, Joussemet dan Dufour which were then designed by the researcher. The results of pre-test and post-test 1 were tested with non prametric Wilcoxon Signed Rank and showed a significant increase between the results of pre-test with post-test 1 and post-test 2. Thus it can be concluded that autonomy support training is effective in improving autonomy support skills of caregivers for toddler, so hopefully TPA X caregivers can be an important agent that give a positive impact on the autonomy of the children.

Keywords: autonomy; autonomy support; caregiver; daycare, toddler.

\section{PENDAHULUAN}

Anak-anak pada usia 18-36 bulan berada pada masa toddler yang merupakan akhir dari masa bayi, pada masa ini anak berkembang untuk mulai mengenal siapa diri mereka (Copple \& Bredekamp, 2009). Karakteristik umum perkembangan anak usia toddler menurut Copple dan Bredekamp (2009) diantaranya anak senang mengeksplorasi dunianya secara fisik maupun sosial, anak menaruh minat untuk mencoba melakukan apa yang dilakukan orang dewasa terdekatnya, anak mulai dapat mengerti instruksi, anak senang mendengar cerita tentang diri mereka sendiri dan hal-hal di sekitarnya walaupun diceritakan berulang-ulang, kesadaran sosial anak meningkat, dan anak mulai dapat mengetahui perasaan orang lain.

Sejalan dengan itu, Côté-Lecaldare, Joussemet dan Dufour (2016) menjelaskan bahwa pada usia toddler anak mulai dapat diajarkan peraturan sehari-hari, 
seperti misalnya mencuci tangan sebelum makan. Tujuan utama dari mengajarkan peraturan adalah agar anak dapat memahami maksud dari adanya peraturan tersebut dan mengatur perilaku yang sesuai.

Seiring dengan kesadaran sosial yang meningkat, anak usia toddler mulai menunjukkan perkembangan kemandirian. Nilai perkembangan kemandirian yang muncul pada anak usia toddler yaitu menunjukkan apa yang menjadi keinginannya (Papalia \& Feldman, 2014). Kemandirian (autonomy) menurut Erikson (dalam Papalia \& Feldman, 2014) adalah ketika anak mengenali apa yang menjadi kehendak/keinginannya dan membuat mereka merasa 'bisa melakukannya'. Anak usia toddler memiliki kecenderungan alami untuk mengeksplorasi lingkungan, namun biasanya anak tidak dibiarkan sendirian dalam melakukannya, anak membutuhkan agen sosialisasi yaitu orangtua atau pengasuh terdekat anak lainnya yang memberikan dukungan agar kemandirian anak dapat terbentuk (autonomy support) (Côté-Lecaldare, Joussemet, \& Dufour, 2016). Dukungan kemandirian merupakan dukungan yang berasal dari agen sosialisasi (lingkungan eksternal) yang ditandai oleh dukungan aktif pada kemampuan anak untuk menjadi mandiri (Ryan, Deci, Grolnick, \& La Guardia, 2015).

Dampak positif dari anak usia toddler yang mendapatkan dukungan kemandirian oleh orangtua baru akan terlihat pada rentang usia anak yang lebih tinggi. Beberapa dampak positif tersebut diantaranya anak memiliki kemampuan mengerjakan tugas yang lebih baik (Frodi, Bridges, \& Grolnick, 1985), anak memiliki kemampuan executive function yang lebih baik, kemampuan executive function merupakan kemampuan untuk bertahan hidup seperti kemampuan beradaptasi, memilih, merencanakan, menyelesaikan masalah, bertanggung jawab dan percaya diri (Bernier, Whipple, \& Carlson, 2010), anak lebih baik dalam menceritakan mengenai kejadian masa lalu (Cleveland, Reese, \& Grolnick, 2007), serta secara jangka panjang anak dapat mengatur regulasi diri (Laurin \& Joussemet, 2017). Dengan demikian, penting bagi orangtua memberikan dukungan kemandirian kepada anak usia toddler untuk meningkatkan beberapa kemampuan pada rentang usia yang lebih tinggi.

Dalam memberikan dukungan kemandirian terhadap anak usia toddler, orangtua terutama ibu memiliki peranan yang paling penting. Namun perkembangan era globalisasi, tuntutan ekonomi, serta kesetaraan peran antara laki-laki dan perempuan saat ini menyebabkan semakin banyak perempuan yang memilih untuk bekerja. Berdasarkan hasil pengolahan data Badan Pusat Statistik (2019), perempuan di Indonesia yang berada pada usia angkatan kerja dan bekerja terus meningkat dari tahun 2015 sejumlah $37.78 \%$ hingga 2018 berjumlah 38,20\%.
Hal tersebut menunjukkan bahwa semakin banyaknya jumlah perempuan yang bekerja, maka semakin banyak pula jumlah ibu yang bekerja. Hal ini menyebabkan waktu bagi ibu bekerja untuk merawat dan mengasuh anaknya menjadi berkurang. Ibu perlu mencari alternatif orang dewasa lainnya yang dapat membantu menggantikan peran ibu dalam mengasuh anak ketika ibu sedang bekerja.

Peran ibu pada umumnya dapat digantikan dengan beberapa alternatif pilihan seperti anggota keluarga terdekat, pengasuh di rumah atau pengasuh di tempat penitipan anak (TPA). Pada kenyataannya, tidak semua ibu yang bekerja bertempat tinggal dekat dengan anggota keluarga lainnya, selain itu banyaknya pemberitaan di media elektronik maupun media sosial mengenai perlakuan pengasuh yang tidak baik terhadap anak menyebabkan tingkat kepercayaan dan rasa aman orang tua terhadap pengasuh di rumah menjadi berkurang, hal ini membuat banyak orangtua yang merasa khawatir jika harus meninggalkan anak di rumah hanya bersama pengasuh. Dengan pertimbangan tersebut menyebabkan saat ini banyak orangtua memilih TPA sebagai alternatif yang dapat dipercaya untuk menitipkan anak dan menggantikan peran ibu dalam mengasuh anak.

Kemendikbud RI (2013) menjelaskan bahwa TPA merupakan salah satu bentuk PAUD pada jalur pendidikan nonformal yang menyelenggarakan program pendidikan sekaligus pengasuhan dan kesejahteraan sosial terhadap anak sejak lahir sampai dengan usia enam tahun. Tujuan program TPA menurut Kemendikbud RI (2013) adalah (1) mengoptimalisasi tumbuh kembang anak dalam pengasuhan, pendidikan, perawatan, perlindungan dan kesejahteraan, (2) mengganti sementara peran orangtua selama bekerja/ditinggal. TPA merupakan tempat anak menghabiskan waktunya selama 8-10 jam per hari, maka tugas ibu dalam mengoptimalisasi tumbuh kembang anak dalam pengasuhan, pendidikan, perawatan, perlindungan dan kesejahteraan dapat digantikan oleh pengasuh selama berada di TPA. TPA sebagai Lembaga yang menyelenggarakan program pendidikan sekaligus pengasuhan, tidak cukup hanya memiliki fasilitas bermain dan belajar yang lengkap, namun TPA juga harus memberikan apa yang dibutuhkan anak pada aspek non fisik salah satunya dalam hal isu perkembangan psikologis yaitu mendukung pertumbuhan kemandirian anak sejak dini. Pengasuh sebagai bagian dari TPA harus memiliki keterampilan untuk melakukan hal-hal yang mendukung kemandirian anak, sehingga diharapkan pengasuh TPA dapat menjadi agen penting yang memberikan dampak positif terhadap kemandirian anak di rentang usia yang lebih tinggi.

Terdapat berbagai macam program yang dilakukan kepada pengasuh TPA dalam hal meningkatkan perkembangan kemandirian anak usia toddler. Program yang banyak dilakukan sebelumnya berfokus kepada pening- 
katan interaksi antara pengasuh/guru di TPA, salah satunya yaitu Early Head Start (EHS). EHS merupakan sebuah program yang dirancang untuk meningkatkan layanan pengembangan anak dan keluarga (Horodynski, Brophy-Herb, Henry, Smith, \& Weatherspoon, 2009). EHS meliputi kunjungan ke rumah, TPA, atau layanan perkembangan anak lainnya (Horodynski et al., 2009). EHS menunjukkan efek kuat pada perilaku pengasuhan positif termasuk kehangatan dan dukungan yang lebih besar dan stimulasi kognitif yang lebih besar, namun program EHS tidak sesuai karena terlalu luas membahas perkembangan anak secara umum dan subjek penelitian diambil dari beberapa fasilitas tempat perkembangan anak sehingga tidak spesifik hanya bagi pengasuh di TPA.

Penelitian di Indonesia yang sebelumnya pernah dilakukan terhadap pengasuh TPA dengan anak usia toddler yaitu menggunakan teknik MLE (Mediated Learning Experience). Teknik ini terdiri dari proses-proses yang sebaiknya dilakukan pengasuh agar pengasuh menjadi mediator yang baik dan membangun interaksi positif dengan anak. Astriani (2012) mengembangkan teknik MLE pada aktivitas berpakaian untuk meningkatkan interaksi antara pengasuh dan anak. Hasil yang didapatkan dari penelitian tersebut adalah teknik MLE efektif dalam meningkatkan kualitas interaksi antara pengasuh dan anak dalam aktivitas berpakaian. Peningkatan kualitas interaksi pengasuh dan anak melalui teknik MLE ini bermanfaat untuk mengembangkan kemampuan kognitif, motorik, dan psikososial (kemandirian) pada anak usia toddler. Namun teknik MLE ini merupakan penelitian kualitatif, sehingga kurang sesuai dengan penelitian ini yang merupakan penelitian kuantitatif..

Côté-Lecaldare, Joussemet, dan Dufour (2016) menjabarkan praktik-praktik dukungan kemandirian untuk diterapkan oleh pengasuh dan pengajar di TPA untuk meningkatkan kemandirian anak usia toddler. FGD (Focus Group Discussion) dan wawancara dilakukan terhadap 8 pengajar TPA di Kanada, dimana seluruh partisipan telah mendapatkan pelatihan yang sesuai dengan kebutuhan pekerjaan mereka selaku pengajar di TPA, salah satunya memahami perkembangan kemandirian anak usia toddler, sehingga hasil dari penelitian ini sesuai dengan kebutuhan perkembangan anak usia toddler. Terdapat 5 domain besar praktik dukungan kemandirian yaitu (1) mengetahui sang toddler (beberapa contoh diantaranya kebiasaan anak, hal-hal yang disukai anak, mengerti apa yang disampaikan anak), (2) menjadi peka dan responsif terhadap anak (contohnya memahami saat dibutuhkan anak), (3) menjadi partner anak (contohnya bermain bersama, membaca bersama), (4) membina anak (contohnya menjadi model, mengajarkan sesuai kemampuan anak), dan (5) memberikan panduan dan masukan yang jelas (contohnya memberikan instruksi sederhana, memberikan tanggapan positif dari setiap perilaku anak).

Kelima domain tersebut penting untuk dipraktikkan dalam keseharian di TPA X, berdasarkan hasil elisitasi yang dilakukan di TPA X. Penelitian ini akan mengadopsi konten praktik dukungan kemandirian kepada anak usia toddler tersebut. Penelitian ini akan dilakukan kepada pengasuh TPA X menggunakan pelatihan dengan dasar experiential learning. Tujuan dari intervensi ini adalah setelah mengikuti pelatihan pengasuh dapat mempraktikkan bagaimana melakukan dukungan kemandirian.

\section{METODE}

Karakteristik partisipan dalam penelitian ini adalah bekerja di TPA X dan belum pernah mengikuti pelatihan serupa sebelumnya. Jenis pengambilan sampel yang digunakan pada penelitian ini adalah nonprobability sampling dan teknik pengambilan sampel yang digunakan adalah accidental sampling. Teknik pengambilan sampel accidental dengan mempertimbangkan kemudahan pengambilan sampel. Disain penelitian yang digunakan pada penelitian ini one group pre-test and post-test design, yakni hanya memiliki satu kelompok perlakuan dan tidak ada kelompok kontrol. Disain tersebut merupakan disain yang datanya diambil sebelum dan setelah intervensi dengan tujuan melihat dampak dari pemberian intervensi (Kumar, 2005), sehingga disain tersebut sesuai dengan kebutuhan penelitian untuk melihat efektivitas pemberian Program Peningkatan Keterampilan Dukungan Kemandirian. Peneliti melakukan pengukuran pada partisipan sebanyak tiga kali, yaitu sebelum dan setelah intervensi, kemudian diukur kembali dua minggu setelah intervensi. Dengan demikian hasil dari pre-test dan post-test ini dapat dibandingkan untuk melihat apakah terdapat perubahan perilaku yang mendukung kemandirian pada partisipan yang sama.

Prosedur penelitian program peningkatan keterampilan dukungan kemandirian untuk pengasuh TPA $\mathrm{X}$ ini dibagi menjadi 3 tahapan, yaitu tahap persiapan, tahap pelaksanaan dan tahap pengolahan data. Tahap persiapan terdiri dari membuat analisis kebutuhan dan menyiapkan instrumen penelitian.

Tahap pelaksanaan terdiri pre-test, intervensi, dan post-test 1 dilaksanakan pada tanggal 28-29 September 2019, selanjutnya post-test 2 dilaksanakan 2 minggu setelahnya yaitu tanggal 12 Oktober 2019. Intervensi merupakan pelatihan Dukungan Kemandirian yang disusun oleh peneliti berdasarkan prinsip experiential learning Kolb. Experiential learning merupakan proses belajar dimana pengetahuan didapat melalui transformasi dari pengalaman (Kolb, 1984). Terdapat 4 tahapan yaitu Concrete 
Experience (CE), Reflective Observation (RO), Abstract Conceptualization (AC) dan Active Experimentation (AE). Melalui tahapan ini diharapkan partisipan dapat lebih memahami materi yang akan disampaikan mengenai Dukungan Kemandirian, oleh karena itu pelatihan tidak hanya diberikan melalui ceramah. Tahapan Concrete Experience (CE) dilakukan dengan cara menonton video pada sesi 1 dan 2, dan studi kasus pada sesi 3. Selanjutnya pada tahapan Reflective Observation (RO), peserta diminta merefleksikan kegiatan yang dilakukan pada tahapan Concrete Experience (CE) dengan pengalaman sebelum pelatihan, kemudian fasilitator membulatkan dengan ceramah singkat yang merupakan tahapan Abstract Conceptualization (AC). Untuk mencapai tahapan Active Experimentation (AE), partisipan diminta untuk membuat program yang akan dilakukan setela pelatihan dan mempresentasikannya. Selanjutnya tahap Pengolahan data dilakukan setelah seluruh data pre-test, post-test 1 dan post-test 2 terkumpul. terkumpul. Instrumen dalam penelitian ini berupa :

1. Modul Pelatihan "Dukungan Kemandirian" yang terdiri dari 5 sesi, yaitu (1) karakteristik toddler, (2) perkembangan kemandirian anak, (3) praktik dukungan kemandirian, (4) pengalamanku sebagai pengasuh, dan (5) program andalanku. Ke-5 sesi dilakukan selama 2 hari dengan durasi 4 jam di hari pertama dan 5 jam di hari kedua. Metode yang digunakan pada sesi 1 dan 2 adalah demonstrasi film, diskusi, dan ceramah. Metode yang digunakan pada sesi 3 adalah studi kasus, diskusi, ceramah, presentasi, dan bermain peran. Metode yang digunakan pada sesi 4 adalah diskusi. Dan selanjutnya metode yang digunakan pada sesi 5 adalah diskusi dan presentasi. Modul pelatihan ini merupakan pegangan bagi peneliti yang di dalamnya tercakup mengenai kegiatan, tujuan, metode dan indikator keberhasilan tiap sesi pelatihan.

2. Buku Saku Peserta Pelatihan merupakan buku berisi materi pelatihan yang dibagikan kepada peserta setelah pelatihan hari pertama selesai, yaitu mengenai karakteristik toddler, perkembangan kemandirian anak dan praktik dukungan kemandirian. Buku ini dibagikan sebagai pegangan bagi peserta untuk membuat program andalan pada sesi terakhir di hari kedua.

3. Kuesioner Pre-test dan Post-test merupakan alat ukur penelitian yang dibuat dengan mengadopsi 18 praktik dukungan kemandirian oleh pengasuh terhadap anak toddler dari Côté-Lecaldare. Alat ukur ini terdiri dari 41 pernyataan dan disusun berdasarkan skala Likert dengan lima alternatif jawaban yaitu Tidak Pernah, Jarang, KadangKadang, Sering, Selalu. Analisis data pada pe- nelitian ini menggunakan metode analisis data kuantitatif Wilcoxon signed rank test yang digunakan untuk melihat perbedaan tingkat keterampilan dukungan kemandirian oleh pengasuh sebelum dan setelah dilakukan intervensi.

Tabel 1. Contoh Item Alat Ukur

\begin{tabular}{|l|l|l|l|l|l|}
\hline \multicolumn{1}{|c|}{ Pernyataan } & $\begin{array}{c}\text { TP } \\
(1)\end{array}$ & $\begin{array}{c}\text { JR } \\
(2)\end{array}$ & $\begin{array}{c}\text { KK } \\
(3)\end{array}$ & $\begin{array}{c}\text { SR } \\
(4)\end{array}$ & $\begin{array}{c}\text { SL } \\
(5)\end{array}$ \\
\hline $\begin{array}{l}\text { Saya mengamati } \\
\text { bagaimana anak } \\
\text { bermain sendiri atau } \\
\text { bersama teman }\end{array}$ & & & & & \\
\hline $\begin{array}{l}\text { Saya menanyakan } \\
\text { perasaan anak saat } \\
\text { terjadi konflik atau } \\
\text { kesal dengan teman- } \\
\text { nya }\end{array}$ & & & & & \\
\hline $\begin{array}{l}\text { Saya mengajak anak } \\
\text { bercerita melalui } \\
\text { gambar yang ada di } \\
\text { pakaiannya }\end{array}$ & & & & & \\
\hline $\begin{array}{l}\text { Saya memberi contoh } \\
\text { cara mengancing baju } \\
\text { dan meminta anak } \\
\text { melanjutkannya }\end{array}$ & & & & & \\
\hline $\begin{array}{l}\text { Saya mengajak anak } \\
\text { bersama-sama mem- } \\
\text { bersihkan makanan } \\
\text { yang tumpah }\end{array}$ & & & & & \\
\hline Keterangan & & & & & \\
\hline
\end{tabular}

Keterangan :

$\mathrm{TP}=$ Tidak Pernah, $\mathrm{JR}=$ Jarang, $\mathrm{KK}=$ Kadang-

Kadang, $\mathrm{SR}=$ Sering, $\mathrm{SL}=$ Selalu

\section{HASIL DAN PEMBAHASAN}

Berdasarkan data yang telah diperoleh, Seluruh partisipan telah memenuhi karakteristik partisipan yang telah ditentukan yaitu bekerja di TPA X dan belum pernah menerima pelatihan serupa sebelumnya.

Berdasarkan hasil analisis pretest dan posttest 1 dan posttest 2 diperoleh hasil penelitian sebagai berikut :

Tabel 2. Deskripsi Data Gain Score Dukungan Kemandirian Pengasuh

\begin{tabular}{|l|c|c|c|c|c|}
\hline \multicolumn{2}{|c|}{ N } & Min & Max & Mean & Std Dev \\
\hline Pre test & 29 & 123 & 176 & 144,34 & 13,31 \\
\hline Posttest 1 & 29 & 145 & 203 & 173,34 & 13,32 \\
\hline Posttest 2 & 29 & 152 & 183 & 166,96 & 12,44 \\
\hline
\end{tabular}

Dari tabel di atas dapat dilihat bahwa skor terendah saat pretest adalah 123 , posttest 1 adalah 145 dan 
posttest 2 adalah 152. Sementara itu nilai tertinggi saat pretest adalah 176, posttest 1 adalah 203 dan posttest 2 adalah 183. Data dalam tabel deskriptif juga menunjukkan peningkatan mean pada pretest, posttest 1 , dan posttest 2 , nilai mean pada pretest adalah 144,34 , pada posttest 1 adalah 173,34 dan pada posttest 2 adalah $166,96$.

Seluruh partisipan mengalami peningkatan skor keterampilan dukungan kemandirian dari pretest ke posttest 1 dan posttest 2 . Sejumlah 19 partisipan mengalami penurunan dari posttest 1 ke posttest 2, namun tetap meningkat jika dibandingkan dengan pretest, sedangkan 10 partisipan mengalami peningkatan dari posttest $1 \mathrm{ke}$ posttest 2 . Hasil ini menunjukkan bahwa partisipan masih mengingat materi dari pelatihan hingga 2 minggu setelah pelatihan. Keterampilan dukungan kemandirian peserta meningkat dari sebelum pelatihan hingga 2 minggu setelah pelatihan.

Uji perbedaan kemampuan awal bertujuan untuk mengetahui apakah perbedaan skor pretest dan posttest signifikan atau tidak. Peneliti melakukan uji non parametric Wilcoxon Signed Rank.

Tabel 3. Tes Statistik Wilcoxon Signed Rank

\begin{tabular}{|c|c|c|}
\hline & Pre-Posttest 1 & Pre-Posttest 2 \\
\hline$Z$ & 4,704 & 4,704 \\
\hline $\begin{array}{c}\text { Asymp. Sig. } \\
\text { (2-tailed) }\end{array}$ & 0,000 & 0,000 \\
\hline
\end{tabular}

Uji perbedaan pada skor pretest dan posttest 1 menunjukkan nilai $\mathrm{Z}$ sebesar 4,704 dan nilai signifikan p.value $0,000(<0,05)$. P value yang kurang dari 0,05 menunjukkan adanya perbedaan signifikan antara nilai pretest dan posttest 1 , yaitu sebelum dan sesudah diberikan intervensi pelatihan terdapat perbedaan pengetahuan mengenai keterampilan dukungan kemandirian. Pada uji perbedaan skor pretest dan posttest 2 menunjukkan hasil nilai $\mathrm{Z}$ sebesar 4,704 dan nilai signifikan p.value 0,000 , maka terdapat perbedaan yang signifikan antara pretest dan posttest 2 , yaitu sebelum dan 2 minggu sesudah diberikan intervensi pelatihan terdapat peningkatan keterampilan ukuran kemandirian.

Peneliti melakukan wawancara terhadap 4 orang partisipan yang memiliki penurunan nilai posttest 1 dan posttest 2 paling besar untuk mengetahui gambaran penyebab turunnya nilai dari posttest 1 ke posttest 2 . Peneliti mendapatkan jawaban dari salah satu subjek bahwa subjek tersebut bertanggung jawab mengasuh bayi maka kesempatan untuk mengasuh toddler memang menjadi lebih sedikit. Sedangkan 3 orang subjek lainnya menyatakan bahwa ada kalanya pengasuh terburu-buru untuk dapat menyelesaikan pekerjaan agar tetap dapat berjalan sesuai dengan jadwal rutinitas harian atau berdekatan dengan waktu penjemputan, hal tersebut menyebabkan pengasuh terpaksa membantu untuk memakaikan baju atau sepatu atau menyuap makanan. Namun pengasuh masih selalu mengingat program yang telah dibuat bersama-sama dan ditempel di ruangan sehingga tiap ada kesempatan, pengasuh tetap mempraktikkan sesuai dengan program yang telah dibuat.

Terdapat beberapa hal yang mendukung keberhasilan pelatihan dukungan kemandirian ini, yaitu diterapkannya metode experiential learning dalam pelatihan, konten di dalam pelatihan dan kerjasama dengan pemilik TPA X untuk mewajibkan karyawan mengikuti pelatihan. Menurut Munandar (2001), metode pelatihan experiential learning merupakan metode pembelajaran yang membuat peserta menghayati peran dan tujuan pelatihan, sehingga partisipan pelatihan dapat lebih memahami mengenai praktik yang mendukung kemandirian. Kegiatan-kegiatan yang disusun berdasarkan daur belajar Kolb mendukung meningkatknya pengetahuan partisipan.

Tahapan concrete experience dimana partisipan diberikan kesempatan menonton video atau berdiskusi menyelesaikan kasus memberikan kesempatan bagipartisipan untuk mendapatkan pengalaman konkrit untuk kemampuan yang diajarkan. Tahap reflective observation yaitu fasilitator menggali pengalaman partisipan mendorong peserta dapat merefleksikan pengalamannya serta mendengarkan refleksi dari peserta lain, sehingga partisipan mampu mengaitkan mengenai kemampuan yang diajarkan dengan pengalamannya mengasuh anak toddler. Tahapan abstract conseptualisation memberikan partisipan pengetahuan secara lebih lengkap melalui ceramah fasilitator dan membuat partisipan mampu menyimpulkan perubahan perilaku yang seharusnya dilakukan. Adanya sesi program andalan dan kesempatan partisipan untuk mempresentasikan program yang telah dibuat merupakan active experimentation yang memberikan kesempatan peserta memunculkan tingkah laku baru yang sebaiknya dilakukan serta mendapatkan umpan balik fasilitator.

Dalam menyampaikan konten pelatihan, metode yang digunakan menggunakan alat bantu visual berupa powerpoint dan video. Video yang ditayangkan dalam mengenalkan karakteristik anak usia toddler dan perilaku benar dan salah dalam mendukung kemandirian anak toddler berkaitan erat dengan keseharian pengasuhan di TPA $\mathrm{X}$, hal tersebut membuat partisipan terlihat antusias, tidak bosan dan terus ingin mengetahui jawaban sebenarnya dari video yang ditayangkan dan terus bersemangat untuk menonton tayangan video selanjutnya. Partisipan selalu bertepuk tangan jika penjelasan jawaban dari fasilitator sesuai dengan jawaban partisipan sebelumnya. Hal ini 
sesuai dengan pendapat Laird (2003) bahwa penggunaan alat bantu visual dapat menambahkan stimulasi sensorik pada saat ceramah.

Menurut pendapat beberapa partisipan saat penutupan pelatihan hari pertama, konten pelatihan yang mengadopsi dari praktik dukungan kemandirian Côté-Lecaldare, Joussemet, dan Dufour (2016) merupakan praktik yang sangat aplikatif untuk diterapkan pada keseharian pengasuhan anak usia toddler di lingkungan TPA X, partisipan terus bersemangat mengikuti pelatihan dari awal hingga akhir karena partisipan tidak merasakan adanya beban berpikir yang berat saat mengikuti pelatihan.

Kegiatan pelatihan yang merupakan bentuk kerjasama peneliti dengan pemilik TPA $X$ juga merupakan hal pendukung keberhasilan penelitian. Kebijakan pemilik TPA X untuk menjadikan pelatihan sebagai program internal training membuat peserta bersedia mengikuti pelatihan selama 2 hari di waktu akhir pekan yang seharusnya merupakan waktu bagi para partisipan untuk beristirahat.

Meskipun demikian, terdapat hal yang menjadi keterbatasan penelitian dan perlu menjadi perhatian serta dikembangkan pada penelitian selanjutnya, antara lain alat ukur hanya dapat digunakan untuk mengukur keterampilan dukungan kemandirian bagi pengasuh TPA saja, sedangkan dukungan kemandirian sebaiknya juga perlu diterapkan oleh orangtua baik ayah atau ibu, alat ukur ini belum sesuai untuk mengukur keterampilan dukungan kemandirian orangtua. Andreadakis, Joussemet \& Mageau (2019) menemukan bahwa dukungan kemandirian yang dilakukan oleh orangtua terhadap anak usia toddler berpengaruh positif terhadap kemampuan internalisasi anak. Penelitian selanjutnya dapat mengembangkan alat ukur menjadi sesuai untuk orangtua.

Selanjutnya, pengukuran keterampilan dukungan kemandirian pretest dan posttest dilakukan melalui metode self-report berupa pengisian kuesioner. Penelitian selanjutnya perlu menambahkan metode observasi agar keterampilan dukungan kemandirian yang sesuai dengan praktik-praktik dukungan kemandirian Côté-Lecaldare, Joussemet, dan Dufour dapat diukur secara lebih luas. Kemudian pada tahap active experimentation pada kegiatan roleplay tidak dilakukan langsung terhadap anak usia toddler, ketika roleplay partisipan hanya berpura-pura seakan-akan sedang melakukan kegiatan bersama anak.

\section{SIMPULAN}

Berdasarkan hasil yang didapatkan dari penelitian ini, dapat disimpulkan bahwa program pelatihan dukungan kemandirian yang diberikan kepada pengasuh TPA $\mathrm{X}$ mampu meningkatkan keterampilan pengasuh dalam mendukung kemandirian anak usia toddler di TPA X. Hal tersebut terlihat dari adanya perbedaan signifikan antara hasil pre-test dan post-test keterampilan dukungan kemandirian pengasuh TPA X, yaitu p.value $0,000(<0,05)$. Hasil ini menunjukkan adanya peningkatan frekuensi seberapa sering pengasuh TPA X melakukan praktik yang mendukung kemandirian anak usia toddler. Bagi penelitian selanjutnya, disarankan agar dilakukan pelatihan dukungan kemandirian yang teritegrasi dengan orangtua. Hal ini bertujuan agar pemberian dukungan kemandirian juga terintegrasi di rumah yang merupakan lingkungan utama anak. Diperlukan juga adanya sesi roleplay yang dilakukan terhadap anak usia toddler agar kegiatan yang dilakukan benar-benar menunjukkan situasi ketikabersama anak. Observasi juga sebaiknya dilakukan untuk mendapatkan data yang lebih luas dalam mengukur keterampilan dukungan kemandirian.

\section{DAFTAR PUSTAKA}

Andreadakis, E., Joussemet, M., \& Mageau, G. A. (2019). How to support toddler's autonomy: Socialization practices reported by parents. Early Education and Development vol. 30 (3), 297-314.

Astriani, B. (2012). Efektivitas teknik mediated learning experience melalui pelatihan untuk meningkatkan kualitas interaksi pengasuh dengan anak usia 24-36 bulan saat kegiatan berpakaian. Depok: Tesis, Universitas Indonesia.

Bernier, A., Whipple, N., \& Carlson, S. M. (2010). From external regulation to self regulation: Early parenting precursors of young children's executive functioning, 81 (1). Child Development, 326339.

BPS. (2019). Persentase tenaga kerja formal menurut jenis kelamin. Jakarta: https://www.bps. go.id/dynamictable/2018/05/16/1313/persentase-tenaga-kerja-formal-menurut-jenis-kelamin-2015---2018.html.

Cleveland, E. S., Reese, E., \& Grolnick, W. S. (2007). Children's engagement and competence in personal recollection: Effect of parents' reminiscing goals. Journal od Experimental Child Psychology, 96, 131-149.

Copple, C., \& Bredekamp, S. (2008). Developmentally appropriate (3rd edition). Washington DC: NAEYC.

Côté-Lecaldare, M., Joussemet, M., \& Dufour, S. (2016). How to support toddlers' autonomy: a qualitative study with child care educators. Early Education and Development, 27 (6), 822-840.

Frodi, A., Bridges, L., \& Grolnick, W. (1985). Correlates of mastery-related behavior: A short-term 
longitudinal study of infants in their second year. Child Development, 56 (5), 1291-1298.

Horodynski, M. A., Brophy-Herb, H., Henry, M., Smith, K. A., \& Weatherspoon, L. (2009). Toddler feeding: Expectations and experiences of low-income african american mothers. Health Education Journal 68 (1), 14-25.

Kemendikbud. (2013). Petunjuk teknis penyelenggaraan taman penitipan anak. Jakarta: Kemendikbud.

Kolb, D. A. (1984). Experiential learning: Experience as the source of learning and development. New Jersey: Prentice Hall.

Laird, D. (2003). Approaches to training and development (3rd ed). Cambridge: Perseus Publishing.
Laurin, J. C., \& Joussemet, M. (2017). Parental autonomy-supportive practices and toddlers' rule internalization: A prospective observational study. Motivation and Emotion, 41 (5), 562-575.

Munandar, A. S. (2001). Psikologi industri dan organisasi. Universitas Indonesia: UI-Press.

Papalia, D. E., \& Feldman, R. D. (2012). Experience human development (12th ed). New York: Mc Graw Hill Education.

Ryan, R. M., Deci, E. L., Grolnick, W. S., \& La Guardia, J. G. (2015). Developmental Psychopathology: Second Edition. New Jersey: John Wiley and Sons Ltd. 